\title{
IT Impact on Innovation at the Individual and Group Level - A Literature Review
}

\author{
Stanislav Mamonov \\ Montclair State University \\ stanislav.mamonov@montclair.edu
}

\author{
Richard Peterson \\ Montclair State University \\ richard.peterson@montclair.edu
}

\begin{abstract}
Information technology (IT) is broadly recognized as an important element that supports innovation within organizations, however there has been relatively little integration of research in Information Systems on this topic. In this literature review, we examine and synthesize studies on the effects of IT in supporting innovation at the individual and group levels of analysis published in the past ten years in the leading Information Systems journals. We find that although innovation is inherently done by individuals and groups, there have been relatively few studies that examined how technology affects the innovation process and outcomes at the individual or group level. Further, much of the extant research is narrowly focused on incremental innovation. Through synthesis of the extant research, we identify opportunities for future research on the role of technology in innovation.
\end{abstract}

\section{Introduction}

Innovation, i.e. development of new products and services as well as entry into new markets, has been long recognized as an essential element of business strategy [55]. Information technology plays an important role in supporting innovation within organizations [38], as well as being a component of innovative product [41] and service offerings [35], and a conduit into new markets [41]. While there is a growing body of literature examining the role of technology in supporting and enabling innovation across different contexts, there has been little theoretical integration within this stream of literature [20].

We take the initial step towards a theoretical integration of the emergent insights here by conducting a literature review of innovation-related research. This study is a part of a broader project that examines interdisciplinary research on the effects of IT on innovation across different levels of analysis. Here we present the results of the initial study which follows the recommendations on literature review development [55] and focuses on the top Information Systems journals as sources of studies with significant theoretical impact.

The following research questions guide our literature review. RQ1: What are the focal innovationrelated constructs at the individual and group levels of analysis in Information Systems? RQ2: Which theoretical perspectives are being applied in studying IT-enabled innovation at the individual and group levels of analysis? RQ3: What is known about the role of IT in supporting individual and group level innovation?

We find that although there have been over 400 studies which examined the role of technology in innovation published in the leading Information Systems journals over the past ten years, only 15 of them conducted analysis at the individual or the group level. Our examination of the extant research through the lens of an innovation typology that distinguishes internal/external, incremental/radical, and closed/open innovations reveals that much of the published research has been focused on incremental innovations. Further, all studies in our review that included innovation-related outcomes are limited to ideated innovation, i.e. innovation that has been conceived, but has not been commercialized yet. The lack of research on commercialized innovation limits the practical relevance of extant research [52] and points to opportunities for developing this stream of research to better understand how information technology can contribute business value through innovation.

The remainder of the manuscript is structured as follows. In Section 2, we provide a brief overview of innovation-related research that guides the framing of our analysis. In Section 3, we discuss the methodology underlying the selection of the studies included in this review, in Section 4, we present the analysis of the selected literature and, in Section 5, we discuss the implication of the results.

\section{Theoretical background}

Innovation has been the focus of research across disciplines [8, 21, 42, 46] and a full review of prior work is beyond the scope of the current manuscript. Here we 
summarize two themes in the organizational innovation research that are relevant to our work. First, we outline a typology that distinguishes different types of innovations. Different innovation types present different challenges and may benefit from different types of IT. Second, we summarize the key factors that have been shown to have a significant effect on innovation in management research. Understanding the organizational factors that impact innovation can help us understanding the interplay between the IT and these organizational factors.

\subsection{Innovation and innovation types}

To understand how information technology can affect innovation at the individual and the group levels within organizations, we need an operating definition of innovation. While many competing definitions of innovation have been proposed [14], we draw on the definition recently developed by Anderson et al. [5] which emphasizes that innovation as a concept describes both the process and the outcomes of "attempts to develop and introduce new ways of doing things." This conceptualization of innovation covers a very broad range of activities and outcomes. With the goal of identifying more coherent subgroups of innovationrelated studies, we further draw on several established typologies of innovation that distinguish 1) internally versus externally focused 2) incremental versus radical, and 3) closed versus open innovation [13, 33, 40].

Internally focused innovation aims at developing new ways of doing things within the organization, whereas externally focused innovation aims at developing new product or service offerings for the markets [15]. The distinction between incremental versus radical innovation is determined in relation to the starting state [16, 17]. Radical innovations are often discussed as disruptions within industries because they introduce fundamentally new products or services and reshape the markets [17], whereas incremental innovations seek to add features or functionality to existing products or services. Internally focused radical innovations reshape value creation within the organizations, commonly offering substantial cost savings and scale benefits to the innovating organizations [27].

Open innovation is distinguished from closed innovation by the participation of external agents, e.g. partners and customers in the innovation process [13]. Open innovation poses novel challenges in terms of structure and governance related to the external agent participation in the innovation process $[18,22]$.

Prior analysis of innovation-related studies in management noted that innovation success is affected by individual and group factors as well as the context within which the innovation is being developed [5]. Different types of innovation contexts present different environmental considerations. By focusing on the specific innovation context subtypes, we aim to synthesize the insights from extant research on the role of IT within the specific contexts and identify opportunities for further research.

\subsection{Organizational factors that affect innovation}

Innovation management has been a very active area of research in management and several authors have offered a synthesis of extant management research $[2,3$, 4, 36, 43]. We draw on Anderson et al. [4] for a summary of factors identified through a systematic analysis of top management journals. In as much as technology can be utilized to support innovation by individual users and groups, the list of known individual and group constructs is helpful in understanding how IT can affect the underlying individual and group processes and outcomes. Anderson et al. [4] provide the following list of factors that have been shown to affect organizational innovation at the individual and group levels of analysis.

\begin{tabular}{|l|l|}
\hline Individual & Group \\
\hline $\begin{array}{l}\text { Personality (self- } \\
\text { confidence, openness to } \\
\text { experience, originality, } \\
\text { etc.) }\end{array}$ & $\begin{array}{l}\text { Team structure } \\
\text { (minority influence, } \\
\text { cohesiveness, longevity, } \\
\text { etc.) }\end{array}$ \\
$\begin{array}{l}\text { Motivation } \\
\text { (intrinsic/extrinsic, } \\
\text { determination to } \\
\text { succeed, etc.) }\end{array}$ & $\begin{array}{l}\text { Team climate } \\
\text { (participation, vision, } \\
\text { norms for innovation, } \\
\text { conflict, constructive } \\
\text { controversy, etc.) }\end{array}$ \\
$\begin{array}{l}\text { Cognitive ability } \\
\text { (intellect, task-specific } \\
\text { knowledge, divergent } \\
\text { thinking, ideational } \\
\text { fluency, etc.) }\end{array}$ & $\begin{array}{l}\text { Team composition } \\
\text { (heterogeneity, } \\
\text { education level, etc.) }\end{array}$ \\
$\begin{array}{l}\text { Job characteristics } \\
\text { (autonomy, span of } \\
\text { control, job demands, } \\
\text { support for innovation, } \\
\text { etc.) }\end{array}$ & $\begin{array}{l}\text { Team processes } \\
\text { (reflexivity, integration } \\
\text { skills, decision-making } \\
\text { style, etc.) }\end{array}$ \\
& $\begin{array}{l}\text { Leadership style } \\
\text { (democratic, } \\
\text { participative, etc.) }\end{array}$ \\
\hline
\end{tabular}

\section{Methodology}


In developing this literature review, we follow the guidelines in [55]. The present study is a part of a larger effort focusing on a comprehensive examination of the role IT in enabling and supporting innovation. Google Scholar returns over 3.5 million results for the "innovation and technology" search phrase. Given the overwhelming volume of research in this domain and following the recommendations in [55], we focused this initial review on the research published in the eight journals in the Information Systems (IS) senior scholars' basket of journals which includes European Journal of Information Systems (EJIS), Information Systems Journal (ISJ), Information Systems Research (ISR), Journal of the Association for Information Systems (JAIS), Journal of Information Technology (JIT), Journal of Management Information Systems (JMIS), Journal of Strategic Information Systems (JSIS), and Management Information Systems Quarterly (MISQ).

To select the studies for the analysis we searched the respective journals for articles containing the word "innovation" in either the title, the abstract or the list of keywords. In aggregate, we retrieved 1178 manuscripts across the eight journals. Table 1 summarizes the manuscript count retrieved from each journal.

Table 1. Distribution of innovation-related studies in the senior scholars' basket of journals

\begin{tabular}{|l|r|r|}
\hline & Search results & \% contribution \\
\hline EJIS & 24 & $2.0 \%$ \\
\hline$I S J$ & 146 & $12.4 \%$ \\
\hline$I S R$ & 282 & $23.9 \%$ \\
\hline$J A I S$ & 67 & $5.7 \%$ \\
\hline$J I T$ & 323 & $27.4 \%$ \\
\hline$J M I S$ & 62 & $5.3 \%$ \\
\hline$J S I S$ & 190 & $16.1 \%$ \\
\hline$M I S Q$ & 84 & $7.1 \%$ \\
\hline
\end{tabular}

In the next step, because our focus is on the role of information technology in innovation, we examined the abstracts and, where necessary, full manuscripts to determine whether IT-enabled innovation was a substantive part of each study. We excluded review articles and editorials from our analysis. The remaining set consisted of 432 studies. Next, we examined the studies to determine the level of analysis in each. For this literature review, we selected only the studies at the individual and group level of analysis. We identified 15 empirical and theoretical studies that focus on the role of information technology in innovation at either of these levels of analysis.

\section{Analysis}

\subsection{Theoretical perspectives and focal innovation-related constructs}

In the first step of our analysis, we examine the theoretical perspectives and focal innovation-related constructs. We find a broad set of theories being employed in the studies focusing on the individual level of analysis. The theoretical perspectives include theories of individual memory activation [9], information processing [53], personality [28], motivation [23], consumer psychology [19] and social capital [31].

We also find a very broad spectrum of dependent constructs and measures used to capture innovationrelated individual perceptions and behaviors. Two studies in our set focus on examining the employee ability to develop innovative ideas or ways of doing work [31, 53]. Two other studies examine idea contributions in online ideation platforms [9, 28] and several studies focus on constructs that are only tangentially related to innovation, e.g. consumer empowerment [19]. Table 2 summarizes the theoretical perspectives and the associated innovation-related construct measurements at the individual level of analysis.

Table 2. Theories and innovation-related construct measures at the individual level of analysis

\begin{tabular}{|c|c|c|}
\hline Study & $\begin{array}{l}\text { Theoretical } \\
\text { perspective }\end{array}$ & $\begin{array}{l}\text { Innovation-related } \\
\text { measurement } \\
\text { construct and } \\
\text { method }\end{array}$ \\
\hline [31] & Social capital & $\begin{array}{l}\text { Not explicitly } \\
\text { defined } \\
\text { Survey }\end{array}$ \\
\hline$[50]$ & Social capital & $\begin{array}{l}\text { Entrepreneurial } \\
\text { success }\end{array}$ \\
\hline [19] & $\begin{array}{l}\text { Consumer } \\
\text { empowerment } \\
\text { theory }\end{array}$ & $\begin{array}{l}\text { Consumer } \\
\text { empowerment } \\
\text { Survey }\end{array}$ \\
\hline [9] & $\begin{array}{l}\text { Spreading in } \\
\text { associative memory }\end{array}$ & $\begin{array}{l}\text { Number, depth and } \\
\text { breadth of generated } \\
\text { ideas. }\end{array}$ \\
\hline$[23]$ & Game theory & Knowledge transfer \\
\hline$[53]$ & Technostress & $\begin{array}{l}\text { ICT-enabled } \\
\text { innovation } \\
\text { Survey }\end{array}$ \\
\hline
\end{tabular}




\begin{tabular}{|l|l|l|}
\hline [28] & Machiavellianism & $\begin{array}{l}\text { Quantity of ideas } \\
\text { and comments } \\
\text { contributed in an } \\
\text { online innovation } \\
\text { platform. }\end{array}$ \\
\hline$[39]$ & $\begin{array}{l}\text { Theory of IT } \\
\text { repurposing }\end{array}$ & $\begin{array}{l}\text { Theory } \\
\text { development, no } \\
\text { empirical data. }\end{array}$ \\
\hline$[24]$ & $\begin{array}{l}\text { Inductive study } \\
\text { relying on } \\
\text { comparative causal } \\
\text { mapping }\end{array}$ & $\begin{array}{l}\text { Effective } \\
\text { knowledge sharing }\end{array}$ \\
\hline$[30]$ & $\begin{array}{l}\text { Diffusion of } \\
\text { innovation }\end{array}$ & $\begin{array}{l}\text { Innovation } \\
\text { legitimacy }\end{array}$ \\
\hline
\end{tabular}

At the group level of analysis, we find fewer studies, but an equally diverse set of theoretical perspectives. While some studies draw on the well-established dynamic capabilities literature [44], others develop context specific theories [47]. Notably, only one of the studies actually includes a measure of innovationrelated activities [44]. Table 3 summarizes the theoretical perspectives and the associated innovationrelated construct measurements at the group level of analysis.

Table 3. Theories and innovation-related construct measures at the group level of analysis

\begin{tabular}{|l|l|l|}
\hline Study & $\begin{array}{l}\text { Theoretical } \\
\text { perspective }\end{array}$ & $\begin{array}{l}\text { Innovation-related } \\
\text { construct and } \\
\text { measurement method }\end{array}$ \\
\hline$[26]$ & $\begin{array}{l}\text { Strategy-as- } \\
\text { practice }\end{array}$ & $\begin{array}{l}\text { Process focus - no } \\
\text { actual measurement } \\
\text { of innovation. }\end{array}$ \\
\hline$[47]$ & $\begin{array}{l}\text { Descriptive case } \\
\text { study - no } \\
\text { overarching theory }\end{array}$ & $\begin{array}{l}\text { Process focus - no } \\
\text { actual measurement } \\
\text { of innovation. }\end{array}$ \\
\hline$[6]$ & $\begin{array}{l}\text { IT } \\
\text { institutionalization }\end{array}$ & $\begin{array}{l}\text { Process focus - no } \\
\text { actual measurement } \\
\text { of innovation. }\end{array}$ \\
\hline$[44]$ & $\begin{array}{l}\text { Dynamic capability } \\
\text { theory }\end{array}$ & $\begin{array}{l}\text { Idea volume and } \\
\text { diversity of ideas }\end{array}$ \\
\hline$[56]$ & $\begin{array}{l}\text { Knowledge } \\
\text { contextualization }\end{array}$ & $\begin{array}{l}\text { Collaboration } \\
\text { capability }\end{array}$ \\
\hline
\end{tabular}

\subsection{IT effects on innovation}

Focusing on the studies that examined IT-supported innovation at the individual level, we find that along with studies examining the traditional IS constructs, e.g. system quality [19] and IT use [31], there are also studies that propose more novel perspectives on the role of technology in innovation. For example, Nevo et al. [39] suggest that technology users can come up with innovative uses for existing IT systems and the authors outline the process that can help guide future research on innovative uses of existing IT systems.

Several studies point to the importance of considering IT users' personality and motives in understanding the technology effects on innovation. For example, a study focusing on the personality effects on the idea and comment contributions in ideation platforms found that Machiavellian personality factors produced a complex set of effects on user activities. While the distrust towards others reduced idea contributions, the need for status was positively associated with commenting. Geng et al. [23] further suggest that misaligned incentives can cause people to share purposefully erroneous information leading to shared knowledge distortion. Tarardar et al. [53] also point out that while technology is commonly seen as a positive factor in optimizing information flow and generation of new ideas, IT can also be a source of technostress that can undermine operational performance. Table 4 summarizes the focal IT-related constructs and key insights from studies on innovation at the individual level.

Table 4. IT effects on innovation - individual level

\begin{tabular}{|c|c|c|}
\hline Study & $\begin{array}{l}\text { Focal IT } \\
\text { construct }\end{array}$ & Insights \\
\hline [31] & $\begin{array}{l}\text { Enterprise- } \\
\text { social } \\
\text { software use }\end{array}$ & $\begin{array}{l}\text { Enterprise social software } \\
\text { enabled inter-team } \\
\text { communications are } \\
\text { associated with innovative } \\
\text { performance }\end{array}$ \\
\hline [19] & $\begin{array}{l}\text { Experienced } \\
\text { tool support }\end{array}$ & $\begin{array}{l}\text { Experienced tool support } \\
\text { has a positive effect on } \\
\text { perceived enjoyment and } \\
\text { perceived empowerment in } \\
\text { product co-design } \\
\text { platforms. }\end{array}$ \\
\hline [9] & $\begin{array}{l}\text { No IT- } \\
\text { related } \\
\text { construct }\end{array}$ & $\begin{array}{l}\text { Priming has a positive } \\
\text { effect on the number, } \\
\text { breadth and depth of } \\
\text { generated ideas. }\end{array}$ \\
\hline [23] & $\begin{array}{l}\text { No IT- } \\
\text { related } \\
\text { construct }\end{array}$ & $\begin{array}{l}\text { Game theoretic modeling } \\
\text { suggests that misaligned } \\
\text { incentives can lead to } \\
\text { shared knowledge } \\
\text { distortion. }\end{array}$ \\
\hline [53] & $\begin{array}{l}\text { Technostress } \\
\text { creators }\end{array}$ & $\begin{array}{l}\text { Technostress can have a } \\
\text { negative effect on } \\
\text { technology user } \\
\text { performance. }\end{array}$ \\
\hline [28] & $\begin{array}{l}\text { No IT- } \\
\text { related } \\
\text { construct }\end{array}$ & $\begin{array}{l}\text { Machiavellianism (distrust } \\
\text { of others, amorality, desire } \\
\text { for status) have a complex } \\
\text { pattern of effects on idea }\end{array}$ \\
\hline
\end{tabular}




\begin{tabular}{|l|l|l|}
\hline [39] & $\begin{array}{l}\text { Technology } \\
\text { reinvention } \\
\text { theory }\end{array}$ & $\begin{array}{l}\text { and comment contributions } \\
\text { in idea generation } \\
\text { platforms. }\end{array}$ \\
$\begin{array}{l}\text { Re-appropriation of } \\
\text { existing technology for } \\
\text { novel uses proceeds } \\
\text { through hypothetic } \\
\text { reinvention, technology re- } \\
\text { composition, reinvention } \\
\text { narrative stages before } \\
\text { yield novel uses. }\end{array}$ \\
\hline$[24]$ & $\begin{array}{l}\text { Perceived } \\
\text { barriers in } \\
\text { software } \\
\text { development }\end{array}$ & $\begin{array}{l}\text { Managers and developers } \\
\text { differ in their perceptions } \\
\text { of the key barriers to } \\
\text { effective knowledge } \\
\text { sharing in agile projects. } \\
\text { Whereas managers are } \\
\text { most concerned about the } \\
\text { project scope, individual } \\
\text { developers are more } \\
\text { concerned about the team } \\
\text { capabilities. }\end{array}$ \\
\hline [50] & $\begin{array}{l}\text { Computer } \\
\text { efficacy }\end{array}$ & $\begin{array}{l}\text { Successful entrepreneurs } \\
\text { have higher general IT self- } \\
\text { efficacy }\end{array}$ \\
\hline [30] & $\begin{array}{l}\text { No IT- } \\
\text { related } \\
\text { construct } \\
\text { innovative systems is } \\
\text { dependent on the new } \\
\text { systems gaining pragmatic, } \\
\text { cognitive, normative and } \\
\text { regulative legitimacy }\end{array}$ \\
\hline
\end{tabular}

At the group level of analysis, we also find a diverse set of IT-related constructs that include routine and innovative IS use, institutionalization of IT, IT business process outsourcing and emergent IT strategy. The studies in this subset also point to the equivocality of IT contribution to innovation. For example, while Roberts, et al. [44] show that innovative uses of IT can help in the environmental opportunity sensing, Baptista et al. [6] show that IT can also impede innovativeness by institutionalizing incumbent business practices. Sandeep et al. [47] emphasize that the success of ITenabled initiatives is often dependent on an external network of social agents. Henfridsson and Lind [26] further point to the fact the enacted IT strategy often emerges in the process of the planned IT strategy execution and it necessarily accommodates the emergent requirements. Table 5 summarizes the focal IT-related constructs and key insights from studies on innovation at the individual level.

Table 5. IT effects on innovation - group level \begin{tabular}{|l|l|l|}
\hline Study & Focal IT construct & Insights \\
\hline
\end{tabular}

\begin{tabular}{|l|l|l|}
\hline [26] & $\begin{array}{l}\text { Emergent IT } \\
\text { strategy }\end{array}$ & $\begin{array}{l}\text { IT strategy is often the } \\
\text { result of a deliberate } \\
\text { plan and emergent } \\
\text { patterns during the } \\
\text { execution process. }\end{array}$ \\
\hline [47] & $\begin{array}{l}\text { IT business } \\
\text { process } \\
\text { outsourcing }\end{array}$ & $\begin{array}{l}\text { The success of } \\
\text { innovative IT business } \\
\text { process outsourcing is } \\
\text { dependent on a } \\
\text { network of social } \\
\text { actors. }\end{array}$ \\
\hline [6] & $\begin{array}{l}\text { Institutionalization } \\
\text { of IT }\end{array}$ & $\begin{array}{l}\text { Institutionalization of } \\
\text { IT can have an } \\
\text { impeding effect on } \\
\text { innovation when } \\
\text { incumbent business } \\
\text { practices are } \\
\text { embedded within IT. }\end{array}$ \\
\hline [44] & $\begin{array}{l}\text { Routine IS use, } \\
\text { Innovative IS use }\end{array}$ & $\begin{array}{l}\text { Innovative IS use can } \\
\text { improve both the } \\
\text { quantity and diversity } \\
\text { of new ideas through } \\
\text { environmental } \\
\text { sensing. }\end{array}$ \\
\hline [56] & $\begin{array}{l}\text { System design } \\
\text { features }\end{array}$ & $\begin{array}{l}\text { System design } \\
\text { features affect } \\
\text { business team } \\
\text { performance through } \\
\text { facilitating knowledge } \\
\text { contextualization and } \\
\text { consequently } \\
\text { increasing } \\
\text { collaboration and } \\
\text { absorptive capacity of } \\
\text { the teams. }\end{array}$ \\
\hline
\end{tabular}

\subsection{Types of innovation and the role of IT}

The success of innovation efforts is greatly dependent on the context [5]. Different types of innovation challenges may benefit from various ITrelated systems and processes. To assess the current state of research in the leading journals in terms of the IT contribution to innovation within different contexts, we examined the IT-related constructs that have been studied in different internally versus externally oriented, incremental versus radical, closed versus open innovation contexts.

We find that there is no conceptual overlap in terms of the focal IT-related constructs in our sample and, consequently, there is little opportunity to generalize across the studies. We find some countervailing insights in the internally focused closed incremental innovation contexts. While a study of enterprise messaging system use suggests that such systems can have a positive effect 
on the internal process innovation within organizations [31], Tarafdar et al. [53] show that IT systems can also introduce information overload and stress, and consequently reduce the opportunities for innovation in internal business practices.

Focusing on open innovation, we find that extant research has primarily focused on externally-oriented innovation efforts and has uncovered that both technical [19] and psychological [24] barriers associated with IT systems meant to support open innovation efforts can interfere with individual contributions. Table 6 summarizes the IT-related construct mappings within different innovation contexts.

Table 6. IT constructs vis-à-vis innovation types individual level

\begin{tabular}{|c|c|c|c|c|}
\hline & Incremental & & Radical & \\
\hline & Closed & Open & Closed & Open \\
\hline 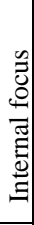 & $\begin{array}{l}\text { Enterprise- } \\
\text { social } \\
\text { software use } \\
\text { [31] } \\
\text { Technostress } \\
\text { [53] }\end{array}$ & & $\begin{array}{l}\text { Computer } \\
\text { efficacy } \\
\text { [50] }\end{array}$ & \\
\hline 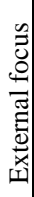 & & $\begin{array}{l}\text { Experienc } \\
\text { ed tool } \\
\text { support } \\
{[19]}\end{array}$ & & $\begin{array}{l}\text { Perceived } \\
\text { barriers in } \\
\text { software } \\
\text { development } \\
{[24]}\end{array}$ \\
\hline
\end{tabular}

The studies analyzing the effects of IT at the group level of analysis have concentrated primarily on closed internal incremental innovation. While several studies have noted the potential positive effects of IT on innovation through novel uses of existing IT systems [44], new system design to support group-level innovation [56], and flexible IT strategy that can accommodate new information during innovative project execution [26], we also find a note of caution pointing to the potential role of IT systems in impeding innovation in cases when the IT systems become de facto institutionalization structures for incumbent business processes [6]. Table 7 summarizes the ITrelated construct mappings within different innovation contexts at the group level of analysis.

\section{Discussion}

\subsection{Theoretical frames and innovation-related constructs}

Focusing on the theoretical frames that are used to examine innovation-related phenomena in Information Systems, we find a broad spectrum of theories being employed, ranging from the spreading in associative memory (SIAM) theory that has been leveraged to understand the effects of priming on creativity in

Table 7. IT constructs vis-à-vis innovation types group level

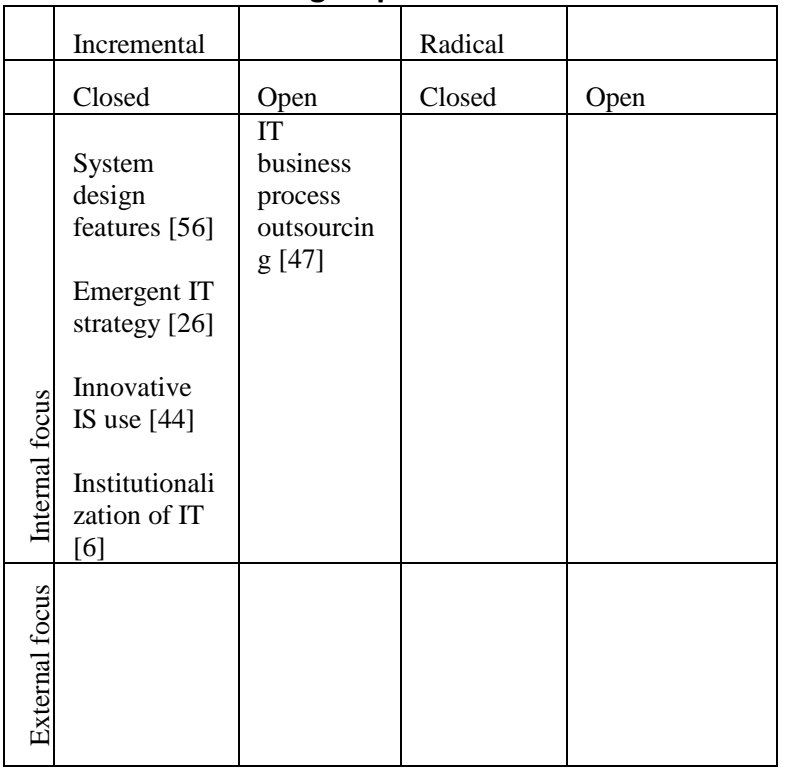

technology-mediated contexts [9] to game theory that provides the foundation for agent-based modeling. We also find a native IS theory which focuses on the process of IT repurposing for novel innovative uses [39].In terms of the dependent innovation-related constructs, we find that most of the group-level studies focus on the processes involved in innovation development without an assessment of the process outcome. At the individuallevel, the studies that include measures of innovation outcomes focused primarily on ideated innovation, e.g. the quantity and quality of ideas contributed in ideation platforms [9, 28].

Commercialized innovations are distinct from ideated innovations in that they actually reach the markets and hopefully create value for the companies [29]. The lack of research that examines how technology can be leveraged towards developing commercially successful innovations limits the practical relevance of insights. Xerox PARC research center famously ideated many innovations, including laser printing, but generally failed to harvest the value from these innovations [11, 12]. At the moment, there is little empirical evidence that the processes that have been studied actually produce business value for the firms. This is an important gap in the current research.

\subsection{Effects of IT on innovation}


Equivocality of IT in the innovation process is the most important insight that emerges in our study. Both at the individual and at the group levels of analysis, we find that technology can have both innovation promoting and innovation impeding effects. At the individual level, IT can facilitate communication to enhance innovation opportunities [31], but IT also be a source of information overload [53]. At the group-level, IT can be useful in sensing external opportunities [44], but IT can also serve as an institutionalization mechanism for established business practices and therefore impede innovation [6].

\subsection{Opportunities for further research}

Studies focusing on the interplay between individual and/or group factors in the innovation process constitute a small minority of innovation-related research in Information Systems. Only 15 of 432 studies in our sample examined the role of information technology at the individual or group level. Provided that innovation is fundamentally a human activity [7,37], it is surprising to find the relative lack of research on how information technology affects both individual and group level innovation processes and outcomes.

We found no studies that examined the role of information technology group-based radical innovation development. Radical innovation is recognized as an essential element of long-term organizational success across industries $[32,49,54]$ and the lack of research on the effects of technology in supporting group-based radical innovation efforts is a clear opportunity for Information Systems research.

We see relatively little integration of insights from innovation management literature in studies that we reviewed. There are only two studies that considered individual motivations [23] or personality [28] in evaluating information sharing and idea contributions respectively. None of the studies focusing on the groupbased innovation considered team structure, team composition, team climate or other group-level constructs known to play a role from the innovation management literature [4]. The integration of known group-level factors and re-evaluation of the effects of technology in technology-mediated group innovation presents an attractive opportunity for further research.

Another surprising finding is the lack of studies that examine the effects of information systems on knowledge sharing in the innovation-related contexts. Knowledge sharing within groups and integration of external knowledge have been shown to be central to the success of innovation efforts within organizations [34, 45]. The effects of technology on knowledge management is a central theme in Information Systems research $[25,45,48]$. There is an opportunity to reevaluate the insights from the decades of research on the role of technology in knowledge management [1] in the innovation related contexts.

Lastly, we did not find any evaluation on the role of technology in the established practice-based innovation frameworks, e.g. the Stanford method or the double diamond method developed by the British Design Council $[3,10,51]$. This is yet another opportunity for future research.

\section{Conclusion}

This study is the first step in a broader effort to integrate insights from research on the role of information systems in innovation. This review focuses on the individual and group levels of analysis and IT equivocality is the key emergent insight. IT can have both positive and negative effects in the innovation process. Our review also reveals that there has been relatively little research on the role of IT in the innovation process and outcomes at the individual and group levels and the published research has generally left out integration with prior efforts in IS and innovation management research. These observations provide clear opportunities for future studies in ITenabled innovation.

\section{References}

[1] Alavi, M., and D. Leidner, "Review: Knowledge management and knowledge management systems: Conceptual foundations and research issues", MIS quarterly 25(1), 2001, pp. 107-136.

[2] Amabile, T., Componential theory of creativity, Harvard Business School, 2011.

[3] Amabile, T., and S. Kramer, The progress principle: Using small wins to ignite joy, engagement, and creativity at work, Harvard Business Press, 2011.

[4] Anderson, N., C.K.W. De Dreu, and B.A. Nijstad, "The routinization of innovation research: A constructively critical review of the state-of-thescience", Journal of Organizational Behavior 25(2), 2004, pp. 147-173.

[5] Anderson, N., K. Potočnik, and J. Zhou, "Innovation and Creativity in Organizations: A Stateof-the-Science Review, Prospective Commentary, and Guiding Framework", Journal of Management 40(5), 2014, pp. 1297-1333.

[6] Baptista, J., S. Newell, and W. Currie, "Paradoxical effects of institutionalisation on the strategic awareness of technology in organisations", Journal of Strategic 
Information Systems 19(3), 2010, pp. 171-183.

[7] Bartel, C.A., and R. Garud, "The role of narratives in sustaining organizational innovation", Organization science 20(1), 2009, pp. 107-117.

[8] Bayus, B., "Crowdsourcing new product ideas over time: An analysis of the Dell IdeaStorm community", Management Science 51(1), 2013, pp. 226-244.

[9] Bhagwatwar, A., A. Massey, and A. Dennis, "Contextual Priming and the Design of 3D Virtual Environments to Improve Group Ideation", Information Systems Research 29(1), 2017, pp. 169185.

[10] Chang Moon, H., A.M. Rugman, and A. Verbeke, "The generalized double diamond approach to international competitiveness", In Beyond the diamond. Emerald Group Publishing Limited, 1995, 97-114.

[11] Chesbrough, H., "Graceful exits and missed opportunities: Xerox's management of its technology spin-off organizations", Business History Review 76(4), 2002, pp. 803-837.

[12] Chesbrough, H., and R.S. Rosenbloom, "The role of the business model in capturing value from innovation: evidence from Xerox Corporation's technology spin-off companies", Industrial and corporate change 11(3), 2002, pp. 529-555.

[13] Chesbrough, H.W., "The era of open innovation", Managing innovation and change 127(3), 2006, pp. 34-41.

[14] Crossan, M.M., and M. Apaydin, "A multidimensional framework of organizational innovation: A systematic review of the literature", Journal of Management Studies 47(6), 2010, pp. 1154-1191.

[15] Davenport, T.H., Process innovation: reengineering work through information technology, Harvard Business Press, 1993.

[16] Dewar, R.D., and J.E. Dutton, "The adoption of radical and incremental innovations: An empirical analysis", Management science 32(11), 1986, pp. 1422-1433.

[17] Ettlie, J.E., W.P. Bridges, and R.D. O'keefe, "Organization strategy and structural differences for radical versus incremental innovation", Management science 30(6), 1984, pp. 682-695.

[18] Felin, T., and T.R. Zenger, "Closed or open innovation? Problem solving and the governance choice”, Research Policy 43(5), 2014, pp. 914-925.
[19] Füller, J., H. Mühlbacher, K. Matzler, and G. Jawecki, "Consumer Empowerment Through InternetBased Co-creation", Journal of Management Information Systems 26(3), 2009, pp. 71-102.

[20] Garcia, R., and R. Calantone, “A critical look at technological innovation typology and innovativeness: a literature review", The Journal of Product Innovation Management 19(2), 2002, pp. 110-132.

[21] Garcia, R., and R. Calantone, "A critical look at technological innovation typology and innovativeness: a literature review", The Journal of Product Innovation Management 19(2), 2002, pp. 110-132.

[22] Gassmann, O., E. Enkel, and H. Chesbrough, "The future of open innovation", $R \& d$ Management 40 (3), 2010, pp. 213-221.

[23] Geng, X., L. Lin, and A.B. Whinston, "Effects of Organizational Learning and Knowledge Transfer on Investment Decisions Under Uncertainty", Journal of Management Information Systems 26(2), 2009, pp. 123-145.

[24] Ghobadi, S., and L. Mathiassen, "Perceived barriers to effective knowledge sharing in agile software teams", Information Systems Journal 26(2), 2016, pp. 95-125.

[25] Guo, Z., and J. Sheffield, "A paradigmatic and methodological examination of knowledge management research: 2000 to 2004", Decision Support Systems 44(3), 2008, pp. 673-688.

[26] Henfridsson, O., and M. Lind, "Information systems strategizing, organizational sub-communities, and the emergence of a sustainability strategy", Journal of Strategic Information Systems 23(1), 2014, pp. 11-28.

[27] Hill, C.W.L., and F.T. Rothaermel, "The performance of incumbent firms in the face of radical technological innovation", Academy of Management Review 28(2), 2003, pp. 257-274.

[28] Hutter, K., J. Füller, J. Hautz, V. Bilgram, and K. Matzler, "Machiavellianism or Morality: Which Behavior Pays off in Online Innovation Contests?", Journal of Management Information Systems 32(3), 2015, pp. 197-228.

[29] Joshi, K.D., L. Chi, A. Datta, and S. Han, "Changing the competitive landscape: Continuous innovation through IT-enabled knowledge capabilities", Information Systems Research 21(3), 2010, pp. 472-495. 
[30] Kaganer, E., S.D. Pawlowski, and S. WileyPatton, "Building Legitimacy for IT Innovations: The Case of Computerized Physician Order Entry Systems", Journal of the Association for Information Systems 11(1), 2010, pp. 1-33.

[31] Kuegler, M., S. Smolnik, and G. Kane, "What's in IT for employees? Understanding the relationship between use and performance in enterprise social software", Journal of Strategic Information Systems 24(2), 2015, pp. 90-112.

[32] Leifer, R., C.M. McDermott, G.C. O'connor, L.S. Peters, M.P. Rice, and R.W. Veryzer Jr, Radical innovation: How mature companies can outsmart upstarts, Harvard Business Press, 2000.

[33] Lewin, A.Y., S. Massini, and C. Peeters, "Microfoundations of internal and external absorptive capacity routines", Organization Science 22(1), 2011, pp. 81-98.

[34] Lin, H.-F., "Knowledge sharing and firm innovation capability: an empirical study", International Journal of manpower 28(3/4), 2007, pp. 315-332.

[35] Lusch, R.F., and S. Nambisan, "Service Innovation: A Service-Dominant-Logic perspective.", MIS Quarterly 39(1), 2015, pp. 155-176.

[36] McLean, L.D., “Organizational culture's influence on creativity and innovation: A review of the literature and implications for human resource development", Advances in developing human resources 7(2), 2005, pp. 226-246.

[37] Mumford, M.D., "Managing creative people: Strategies and tactics for innovation", Human resource management review 10(3), 2000, pp. 313-351.

[38] Nambisan, S., K. Lyytinen, A. Majchrzak, and M. Song, "Information technology and innovation", Special Issue MIS, 2014.

[39] Nevo, S., D. Nevo, and A. Pinsonneault, “A Temporally Situated Self-Agency Theory of Information Technology Reinvention", MIS Quarterly 40(1), 2016, pp. 157-186.

[40] Norman, D.A., and R. Verganti, "Incremental and radical innovation: Design research vs. technology and meaning change", Design issues 30(1), 2014, pp. 7896.

[41] Ping, S., -Ju Wu, D.W. Straub, and T.-P. Liang, "How Information Technology Governance
Mechanisms and Strategic Alignment Influence Organizational Performance: Insights From a Matched Survey of Business and It Managers 1", MIS Quarterly 39(2), 2015, pp. 497-518.

[42] Priem, R.L., S. Li, and J.C. Carr, "Insights and new directions from demand-side approaches to technology innovation, entrepreneurship, and strategic management research", Journal of management 38(1), 2012, pp. 346-374.

[43] Read, A., "Determinants of successful organisational innovation: a review of current research", Journal of Management Practice 3(1), 2000, pp. 95-119.

[44] Roberts, N., D.E. Campbell, and L.R. Vijayasarathy, "Using Information Systems to Sense Opportunities for Innovation: Integrating Postadoptive Use Behaviors with the Dynamic Managerial Capability Perspective", Journal of Management Information Systems 33(1), 2016, pp. 45-69.

[45] Sáenz, J., N. Aramburu, and O. Rivera, "Knowledge sharing and innovation performance: A comparison between high-tech and low-tech companies", Journal of Intellectual Capital 10(1), 2009, pp. 22-36.

[46] Saldanha, T.J. V., S. Mithas, and M.S. Krishnan, "Leveraging Customer Involvement for Fueling Innovation: The Role of Relational and Analytical Information Processing Capabilities", MIS Quarterly 41(1), 2017, pp. 367-396.

[47] Sandeep, M.S., and M.N. Ravishankar, "Social innovations in outsourcing: An empirical investigation of impact sourcing companies in India", Journal of Strategic Information Systems 24(4), 2015, pp. 270288.

[48] Schultze, U., and D.E. Leidner, "Studying knowledge management in information systems research: discourses and theoretical assumptions", MIS quarterly, 2002, pp. 213-242.

[49] Sorescu, A.B., R.K. Chandy, and J.C. Prabhu, "Sources and financial consequences of radical innovation: Insights from pharmaceuticals", Journal of marketing 67(4), 2003, pp. 82-102.

[50] Spiegel, O., P. Abbassi, M.P. Zylka, D. Schlagwein, K. Fischbach, and D. Schoder, "Business model development, founders' social capital and the success of early stage internet start-ups: a mixedmethod study", Information Systems Journal 26(5), 2016, pp. 421-449. 
[51] Von Stamm, B., Managing innovation, design and creativity, John Wiley \& Sons, 2008.

[52] Straub, D., and S. Ang, "Editor's comments: Rigor and relevance in IS research: Redefining the debate and a call for future research", MIS quarterly, 2011, pp. iii-xi.

[53] Tarafdar, M., Q. Tu, and T.S. Ragu-Nathan, "Impact of Technostress on End-User Satisfaction and Performance", Journal of Management Information Systems 27(3), 2010, pp. 303-334.

\section{Appendix - Study summaries}

\begin{tabular}{|c|c|}
\hline Ref & Summary \\
\hline [10] & $\begin{array}{l}\text { The study focuses on the use enterprise social } \\
\text { systems (ESS) in the UK. It finds that intra-team } \\
\text { ESS use is associated with an increase in the } \\
\text { routine task performance and Inter-team ESS use } \\
\text { is associated with innovativeness. }\end{array}$ \\
\hline [6] & $\begin{array}{l}\text { A field study focusing on the geographic } \\
\text { separation effect in collaboration technology use, } \\
\text { involving one co-located and one distributed } \\
\text { team at IBM. The authors show that distributed } \\
\text { teams rely more on knowledge codification and } \\
\text { less on broadcast emails to coordinate their work. }\end{array}$ \\
\hline [7] & $\begin{array}{l}\text { The study examines processes and contingencies } \\
\text { that affect the emergent strategy formulation. It } \\
\text { followed four subgroups within an automaker. } \\
\text { The study illustrates that strategy formulation is a } \\
\text { dynamic process within the organizations. }\end{array}$ \\
\hline [13] & $\begin{array}{l}\text { The study explores how companies engage in } \\
\text { impact sourcing in India. Impact sourcing is } \\
\text { bringing digitally-enabled outsourcing jobs to } \\
\text { marginalized communities. It shows that Indian } \\
\text { entrepreneurs developed a number of different } \\
\text { strategies to engage underprivileged communities } \\
\text { in servicing outsourced positions. }\end{array}$ \\
\hline [1] & $\begin{array}{l}\text { The longitudinal study examines the impact of } \\
\text { the institutionalization of a particular IT on the } \\
\text { strategic awareness and use of IT in the } \\
\text { organization. The case study shows that adoption } \\
\text { of an intranet at a bank resulted in } \\
\text { institutionalization of different business practices } \\
\text { within the intranet and made it challenging for } \\
\text { management to become aware of novel strategic } \\
\text { opportunities. }\end{array}$ \\
\hline [4] & $\begin{array}{l}\text { The study evaluates factors that affect user } \\
\text { empowerment perceptions in product co-creation } \\
\text { platforms. It finds that individual characteristics } \\
\text { (degree of product involvement, creativity) and }\end{array}$ \\
\hline
\end{tabular}

[54] Utterback, J., "Mastering the dynamics of innovation: how companies can seize opportunities in the face of technological change", 1994.

[55] Webster, J., and R.T. Watson, "Analyzing the past to prepare for the future: Writing a literature review", MIS quarterly, 2002, pp. xiii-xxiii.

[56] Zhang, X., V. Venkatesh, and S.A. Brown, "Designing Collaborative Systems to Enhance Team Performance", Journal of the Association for Information Systems 12(8), 2011, pp. 556-584.

\begin{tabular}{|l|l|}
\hline & $\begin{array}{l}\text { the quality of the design tools affect the } \\
\text { individual perceptions of empowerment. }\end{array}$ \\
\hline$[2]$ & $\begin{array}{l}\text { The study looks at how priming affects idea } \\
\text { generation. It finds that priming can lead to an } \\
\text { increase in the number, breadth and depth of } \\
\text { generated ideas. }\end{array}$ \\
\hline$[5]$ & $\begin{array}{l}\text { The study examines how misalignment of } \\
\text { incentives affects organizational learning. } \\
\text { Managers with misaligned incentives may distort } \\
\text { shared knowledge. }\end{array}$ \\
\hline$[15]$ & $\begin{array}{l}\text { The study explores how organizations can } \\
\text { overcome technostress and support innovation. } \\
\text { Innovation support can help reduce technostress } \\
\text { and promote innovation. }\end{array}$ \\
\hline$[8]$ & $\begin{array}{l}\text { The study examines how Machiavellianism } \\
\text { affects idea and comment contribution in online } \\
\text { ideation platforms. It finds that distrust of others } \\
\text { is associated with a greater number of ideas, } \\
\text { whereas amorality and desire for status is } \\
\text { associated with a lower number of contributed } \\
\text { ideas. }\end{array}$ \\
\hline$[11]$ & $\begin{array}{l}\text { Theory development focusing on novel uses for } \\
\text { IT. Novel applications of existing IT develop } \\
\text { through stages: hypothetical reinvention, } \\
\text { technology recomposition, reinvention narratives, } \\
\text { practical experimentation }\end{array}$ \\
\hline$[14]$ & $\begin{array}{l}\text { The study focuses on actual IT use. It finds that } \\
\text { technology use is subject to adaptation of } \\
\text { technology and adaptation of task. }\end{array}$ \\
\hline$[12]$ & $\begin{array}{l}\text { The study examines how the organizational } \\
\text { environment affect dynamic managerial } \\
\text { capabilities. It finds that innovative IS use, } \\
\text { autonomy and innovativeness have a positive } \\
\text { relationship with the number and diversity of } \\
\text { ideas. }\end{array}$ \\
\hline
\end{tabular}

